\title{
THE PHOTOGRAPHS I NEVER GOT!
}

KEITH BARR, 40 Richardson Crescent, Regina, Saskatchewan. S4S 4J3

You should see some of my photographs I never got. I have had trouble taking pictures from day one! I was given a $35 \mathrm{~mm}$ range finder camera way back in 1957 . With this type of camera you have to focus, set the speed, read the light meter and set the aperture. Here is what happened the first time I went to take a picture:

I see a large bird sitting on the ground in an open field. I approach and get quite close. While trying to set everything right on my camera, two men approach the bird, get inside it and fly away. Oh, did I forget to mention that this was a whirly bird? As the helicopter flies away I am still trying to get my camera set right.

Twenty years later... different camera . . . still problems. I am in Wascana Park when I see my first Varied Thrush. I would like to get a picture of this bird so I drive home and get the camera, $600-\mathrm{mm}$ lens and a roll of film. So as not to waste time, I load the film in the camera while waiting at a red traffic light. Back at the park I take several photos of the Varied Thrush. I am sure these pictures will be the envy of National Geographic photographers. But I have not made sure that the film was loaded properly for, as I took 28 exposures on a 24-exposure roll, I realized it had not advanced at all!

Then I got a camera that does it all (almost) ... you just focus and the camera does the rest. There is a
Townsend Solitaire in the juniper that surrounds the museum. I have my trusty camera with me and am able to get close enough to the bird so that it fills the whole frame. I take several pictures. These will be excellent pictures, as no branches hide any part of the bird. I can see the white eye ring and the buff colour on the side and it is just the right angle! During the coming week I take several more pictures. I happen to check the counter and see that it is at 27. Oh! I must have a 36 exposure roll in the camera. A few weeks later, the counter shows 39. My heart sinks all the way to my toes when I open the camera and find that all my beautiful pictures are not to be. I have no film in the camera!

It is spring and I am going birdwatching. I grab my two faithless cameras. I know there is film in the camera with the short telephoto lens but no film in the camera with the long $600-\mathrm{mm}$ lens. I put this camera in the trunk of the car as it is too heavy to carry. I have made several stops along the way. Now I stop at a slough and spot a Red-necked Grebe, uncommon in this area. It is quite close to the road. It is feeding and stays under the water about 20 seconds each time it dives. I jump out of the car, open the trunk, grab the camera with the long $600-\mathrm{mm}$ lens and get back into the car before the grebe surfaces. I take several shots of this male red-neck. That evening, my wife and $I$ are sitting watching T.V. All of a sudden I start to laugh. My wife looks at me rather oddly, as there is only a dull 
commercial on the screen. She asks me what I am laughing at. I tell her about the fantastic pictures I took of the Red-necked Grebe and how just now I remembered that the camera I had used had no film in it!

Now I have a camera that really does everything. All you do is put the film in, shut the back and it loads the film. It automatically sets the speed, the aperture and even focuses automatically! All I should have to do is point and push the button. But which button? It has several little buttons and switches that you can push so that it will do different things, like take five pictures a second. So now instead of just one lousy picture, I get five lousy pictures of the same thing! I also find that since I have had this new camera, I seem to be buying more film. But at least now I know that I will get a picture no matter how bad!

\section{ANNOUNCEMENT}

\section{SASKATCHEWAN CHRISTMAS BIRD AND MAMMAL COUNTS - 1993}

The dates for the Christmas Bird and Mammal counts this year are Friday, 17 December 1993, through Monday, 3 January 1994, inclusive. Count area should be a circle $24 \mathrm{~km}$ (15 mi.) in diameter. Counts must be a minimum of three hours in duration. An information package, including count forms, will be mailed to all previous count compilers in early December. Anyone wishing to initiate a new count should contact:

Wayne C. Harris

Box 414, Raymore, Saskatchewan. S0A 3J0

Phone (306) 746-4544 (answering machine)

Fax (306) 746-4519

All counts must arrive by Monday, 10 January 1994, to be included in the compilation scheduled to appear in the March 1994 Blue Jay. 